\title{
Implementation of Literacy Programs in Basic High School Class
}

\author{
Maryam Isnaini Damayanti \\ Department of Primary Teacher Education \\ Universitas Negeri Surabaya, Indonesia \\ maryamdamayanti@unesa.ac.id
}

\author{
Wahyu Sukartiningsih \\ Department of Primary Teacher Education \\ Universitas Negeri Surabaya, Indonesia \\ wahyusukartiningsih@unesa.ac.id
}

\author{
Endang Darmawati \\ Department of Primary Teacher Education \\ Universitas Negeri Surabaya, Indonesia \\ endangdarmawati@unesa.ac.id
}

\begin{abstract}
Literacy programs develop the language skills of high-class students, especially reading and writing skills. For this reason, good understanding and the optimal role of all elements are needed so that the program can be further developed in a variety of meaningful activities. This study aims to describe the understanding of teachers, the condition of students and the supporting and inhibiting factors for the implementation of literacy programs in high school elementary schools. The results of the study indicate that the understanding of high-class teachers in the three primary schools is categorized as good. This can be seen from the fact that the literacy program in the high class has been carried out in activities that are diverse and meaningful both independent and integrated with learning. The condition of students has increased in terms of reading interest and language skills especially reading and writing. There are supporting factors such as reading angles in each class as well as donations of books from parents and inhibiting factors such as the diversity of reading interests and students' reading comprehension abilities. Based on the results of the study, it can be concluded that the Literacy Program in schools becomes an inseparable part in an effort to prepare high-class students to become candidates for class VII students with a strong reading comprehension ability. For this reason, all elements are obliged to make the program successful in order to be more optimal.
\end{abstract}

Keywords: implementation, literacy program

\section{INTRODUCTION}

Reading and writing are important activities in the era of globalization because in communicating humans are no longer limited to space and time. In this era, the delivery of information is no longer dominated by oral delivery, but also in writing. The use of writing as a means of conveying information can only be done by people who are able to read and write. Readers as recipients of information need to understand the meaning conveyed through written symbols.

As for the author productively conveying his ideas through written symbols. Someone who is not able to use writing well will have difficulty in utilizing various technology products because in general the instructions for using technology products are delivered in writing. In other words, the ability to read and write must be mastered by everyone who lives in this era.

Reading is a receptive activity, namely receiving information from written sources. Receptive words can be interpreted as accepting. Even though it is receptive, the reader is actually not just accepting, but producing understanding according to his reasoning abilities. In this case, the reader does not just accept but also assimilates the contents of the text with prior knowledge.

Given that prior knowledge of each person is different from other people, the results of understanding each person is often different from other people. This is in line with the opinion of Harvey and Goudvis (2000) that in reading there are demands to think about the words that have been read in order to construct meaning.
Competence of spiritual attitudes and social attitudes, achieved through indirect learning (indirect teaching), namely exemplary, habituation, and school culture by paying attention to the characteristics of subjects and the needs and conditions of students. Competence of knowledge and skills is achieved through classroom learning.

Some examples of indicators in high school elementary schools, including conveying new knowledge from nonfiction texts into writing in their own language, convey the results of comparing old knowledge with new knowledge in writing with their own language, presenting interrelated concepts in nonfiction texts to in writing with their own language, convey the results of comparing the expected information with information obtained after reading nonfiction texts verbally, written, and visually.

The various skills indicators above illustrate that to achieve their competence, children are always related to reading and writing activities. Read various kinds of texts and write creatively in re-disclosure as a fruit of understanding the contents of the text. This condition is in line with the opinion of Burns, Roe., and Ross (1996) that reading is an activity of understanding the message or content contained in the text.

One indicator of understanding the text content is that children can retell in writing the contents of the text in their language. Writing the results of understanding can help organize the material that the child will tell. Thus, writing skills have an important role in improving the quality of storytelling, both the quality of completeness, 
demand, and development. Competencies obtained in high class are very important competencies to achieve competency in advanced classes.

The failure of achieving literacy competencies (reading and writing) in the high class will make students experience serious learning difficulties in the following classes. In the sense that literacy learning in the high class must be able to provide adequate competency provision to students in reading and writing so that they can go through the next level of education (class VII and so on) well and optimally.

The implementation of literacy in high class requires students to have the ability to read fluently and write well. According to Tomkins (2011), the ability to read fluently is realized by accuracy, speed, and prosody. Accuracy is the ability to automatically recognize words in the text without any doubt. Smoothness is related to the speed of reading. According to him, up to class III children should be able to read at least 100 words per minute. While prosody is interpreted as reading accompanied by expressive rhythmic and accompanied by the accuracy of phrases and intonations.

Regarding the ability to write, good writing is writing that can convey the author's message to the reader. This is by following with Craig (2013) which indicates good writing from two sides, namely the reader's side and the sentence side. Viewed from the reader's side, good writing is not only easy to read but also easy to understand, fun, and interesting for the reader. While good writing from the side of the sentence is not showing any grammatical errors.

Literacy programs in high class principally encourage students to interact intensely and deeply with reading texts or reading books so they can capture the author's message and take valuable life lessons in it. Activities in this Literacy program also develop communication and collaboration competencies between students and teachers and between students.

This Literacy Program has enormous benefits, especially in preparing high-class students with the ability to read solid understanding and writing. For that reason, the understanding and active role of all elements are highly expected so that the program can run continuously and optimally.

To find out more about the implementation of the literacy program contained in the School Literacy Movement, this research needs to be done to explore more deeply what it is and how it can be implemented in high school elementary schools. The results of this study are expected to be used as input for holders of the Literacy Program implementation policy. Therefore, the study was entitled "Implementation of Literacy Programs in High Schools in Primary Schools".

Based on the background of the above problems, the research objectives that can be formulated are to describe: the implementation of literacy programs in high school classrooms, teacher understanding of the implementation of Literacy programs, the condition of students in the implementation of Literacy programs, and supporting and inhibiting factors for the implementation of Literacy programs in high class Elementary school.

\section{METHOD}

Based on the problems studied, this type of research is classified as qualitative descriptive research. In this qualitative descriptive study, the research data taken is qualitative in the form of information about the implementation of the Literacy Program in high school elementary schools. The research targets were Principals, teachers, and high-class students from 3 elementary schools in the West Surabaya area, namely SDN Lidah Kulon III, SDN Jeruk II, and SDN Lakarsantri II Surabaya, East Java, Indonesia, to explore information about implementation, teacher understanding, student conditions, and supporting and inhibiting factors in the Literacy program in high school elementary schools.

The research data are the results of interviews, notes on observations, answers to questionnaires, closed questionnaires, and documentation about literacy programs in the elementary school's high class, student conditions, and supporting and inhibiting factors in the implementation of literacy programs in high school elementary schools.

Data retrieval research was conducted using the method of interview, observation, questionnaire, closed student questionnaire, and documentation. The instruments needed are:

1. Interview sheet that contains a collection of questions to obtain data on implementation, teacher understanding, student conditions, and supporting and inhibiting factors for the implementation of Literacy Programs in high school elementary school;

2. Observation sheets are used to obtain information in the form of description, condition, and situation about implementation, teacher's understanding, student's condition, and supporting and inhibiting factors for the implementation of Literacy Program in elementary school high class;

3. Questionnaire sheet to obtain information in the form of respondents' answers to the questions asked related to implementation, teacher understanding, student conditions, and supporting and inhibiting factors for the implementation of Literacy Programs in high school elementary schools;

4. Questionnaire sheets students used to obtain information about students' responses as the subject of this literacy program which simultaneously illustrates implement training, teacher understanding, student conditions, and supporting and inhibiting factors in the implementation of literacy programs in high school elementary schools.

Data obtained, then processed, analyzed, concluded, and presented with a description of the implementation, teacher understanding, and condition of students, as well as supporting and inhibiting factors for the implementation of Literacy Program in high school elementary school.

\section{RESULTS AND DISCUSSION}

By following the formulation of the research problem, it can be explained the results of a qualitative descriptive study which is a general description of the 
implementation of Literacy programs in high school elementary schools, namely:

1. Teacher's Understanding of Literacy Programs in the High School of Primary Schools

Data collection was carried out in three public elementary schools in the West Surabaya area, namely Lidah Kulon III Elementary School, Jeruk II Elementary School, and Surabaya Lakarsantri II Elementary School. Data sources are high-class teachers, namely classes IV, $\mathrm{V}$, and VI. Based on the results of interviews in each primary school, in general, it can be explained about the teacher's understanding of the Literacy Program in the high class, namely the teacher's understanding of this program is categorized as good. This can be seen from the implementation of literacy programs in recent years. Teachers play an active role in the implementation of literacy in both the school and in their respective classes, including, namely:

a. Linking literacy activities with the commemoration of the National Day and the Great Day of Religion;

b. Linking the development of learning tools and implementing learning with literacy programs in the high class;

c. Encourage students to actively visit the library, read the collection of books provided, and be creative in the product as a form of understanding the contents of the books read

d. Encourage students to be active in scheduled activities to the library once a week with activities facilitated by library officials that link students' reading to the material contained in learning;

e. Encourage students to dare to express themselves in the work and then display the best student work in the class on the school wall magazine or display wall outside each room in the school.

Implementation in class is the implementation of reading activities for 15 minutes at the beginning of students entering the class or before learning begins. Activities carried out by both individuals and groups. Activities carried out by the teacher in detail can be observed in the exposure below:

a. Provide opportunities for students to take advantage of reading corners, read available books, and interact optimally with books that are read by developing collaboration and communication competencies with both teachers and friends;

b. Assign students to read silently/ comprehensively with various tasks such as identifying and writing the main sentence / main mind along with the explanatory sentence;

c. Assign students to identify important information contained in the reading;

d. Assign students to write information that has been known with information that they want to know from reading;

e. Assign students to answer questions related to the contents of the reading;

f. Assign students to make $5 \mathrm{~W}+1 \mathrm{H}$ questions based on reading;

g. Assign students to write messages that can be captured from reading and present in front of friends; h. Assign students to write valuable life lessons that can be taken from reading;

i. Assign students to rewrite the contents of the reading using their language;

j. Assign students to make simple drama scripts based on reading and then display role-playing in front of friends;

k. Assign students to retell the contents of the reading using their language and verbally;

1. Assign students to use the library or reading corner as a source of learning when PBM.

In addition to the above activities, the teacher functions as a coordinator and facilitator for students in literacy activities. Also, besides, the teacher exemplifies good reading by utilizing a collection of books available in the library, in the classroom, or taken from the home. It appears that teachers and students together carry out reading activities before being creative in the next activity.

Literacy programs that can run for several years with diverse, creative and quality activities, illustrate that the understanding of high-class teachers on literacy programs in this school is well categorized.

2. Students' Conditions in Implementing Literacy Programs in High Schools in Primary Schools

In general, students in each high class can be divided into several conditions, namely students with high reading interest, students with moderate reading interests, and students with a low reading interest.

a. Students with High Reading Interest

Students with high reading interest are students with the conditions prepared in the literacy program held at the school. By actively participating in literacy activities, they benefit more than others. One of the benefits obtained is the development of their language skills both listening, speaking, reading and writing optimally. Also, besides, their knowledge of knowledge has developed so that they facilitate they are completing learning tasks.

In literacy activities, the attitude they usually show is asking questions because they are driven by great curiosity, confidence in answering questions, accepting assignments given with enthusiasm and joy, easy to communicate and collaborate with teachers and friends, think creatively and innovatively, complete tasks well and on time. Regarding the closed questionnaire shared, students with high reading interest showed a tendency to answer YES for all statements given.

\section{b. Students with Moderate Reading Interest}

The second category is students with a moderate reading interest. These students are less likely to participate in literacy activities. If they are excited, they will take part in the activity well. However, if they are not enthusiastic, they cannot complete the literacy task given by both the teacher and the library officer. Students with this condition, usually because of lack of attention from parents because parents are busy earning a living and parents care less about children's education. 
Regarding the closed questionnaire shared, these students showed a tendency to answer NO to statements that would indeed be answered YES by students who have high reading interest. (I always wait for the bell to ring so that I can immediately read the book in the reading corner of the class before learning begins, I want the program this continues to run in my class, etc.).

\section{c. Students with Low Reading Interest}

The third category is students with less or low reading interest. They are students who are in a condition not ready for literacy activities Many factors influence the condition of lack or low reading interest, including parents / families who do not understand the benefits of this literacy program and the influence of the family / surrounding environment.

Based on the stories conveyed by the teacher, usually the background of their parents' conditions are: 1) divorced and parents attach importance to their happiness and forget about the physical, spiritual, and psychological needs of children, 2) too busy earning a living, and 3) lack of knowledge do not understand well about the tremendous benefits of literacy programs carried out at school.

Low or lack of reading interest results in low or lack of enthusiasm in literacy activities. For them, literacy activities are a tedious activity because it is difficult to understand the meaning of reading and it only adds to their task burden. It seems they cannot do the task with focus because from the beginning they did not follow the instructions and direction of the teacher well so they did not understand the purpose of the task well and the assignment that was given also could not be completed properly and on time.

Regarding the closed questionnaire that was distributed, students showed a tendency to answer NO to the statements given. Many students answer NO to the statement "I want this program to continue in my class" and "I always wait for the bell to ring so that I can immediately read the book in the reading corner of the class before learning begins".

3. Supporting and Inhibiting Factors of Literacy Programs in High Schools in Primary Schools

No matter how good an activity program is, it will not escape shortages There are always supporting factors and inhibiting factors. However, the most important thing is how to respond to any existing / emerging conditions. If something is the cause of a good and better program, it should be maintained and encouraged. Conversely, if things appear that are obstacles to the implementation of a program properly and effectively, then ways must be sought to eliminate it or at least eliminate it.

Based on the results of interviews and questionnaires with several respondents/sources, several things can be identified that support the implementation of this literacy program properly and successfully, namely:

a. A good understanding of all existing components of this literacy program (on understanding, benefits, methods or implementation techniques, etc.) of this literacy program). b. Cooperation can be established by all components in the implementation of this literacy program.

c. The active role of parents in supporting children to actively participate in the program and in adding to the existing collection of books.

d. Integrative thematic learning that connects the between subject matter opens opportunities for more diverse literacy activities that can be carried out according to learning.

e. Supporting infrastructure facilities such as the presence of a school library, reading corners in each class, the availability of a diverse collection of books.

In addition to the supporting factors above, there are also optimal barriers to the implementation of literacy programs in this school, such as:

a. Interest in reading diverse students.

b. The condition of students' readiness varies both physically and psychologically.

c. Diverse reading comprehension skills of students.

d. The construction of schools that have not been completed so that the library space is forced to be placed on the second floor (conditional, at SDN Lakarsantri 2).

So far, the effort that can be made by the teacher is to continue to provide assistance and socialization to the leadership and students. The teacher always strives to involve students in activities both outside and inside the classroom. Based on the explanation above, the discussion can be stated as follows:

a. That understanding of a program is very important for the success of the activity or program. As explained in the literature review, literacy is not only developed through activities outside the classroom (in the library) but also in the classroom so that literacy programs need to be integrated into daily learning in the classroom. Thus, teachers need to understand and be skilled about what and how the literacy program can be carried out in high school elementary classes.

b. That literacy program involves reading skills in a fairly large percentage. For this reason, teachers must ensure that students in their class have adequate reading comprehension skills. If there are some students have not achieved adequate reading comprehension skills, it is that they will certainly experience problems when faced with the task of reading the text comprehension or the reading provided. The literacy program places students in thinking activities to understand the intent and message of reading rather than just reading a row of words that appear. This is by following the opinion expressed by Harvey \& Goudvis (2000) that in reading there are demands to think about the words that have been read to construct meaning. While Burns., Roe., \& Ross (1996) reinforce the opinion that reading is an activity to understand the message or content contained in the text. One indicator that students can understand the contents or text messages that are read is that students can retell the contents of the story by using their language and can mention the author's message contained in the reading text. For 
this reason, teachers need to always improve the ability to read students' understanding and always convey to students about the benefits students can get through this literacy activity. With a good understanding of the benefits of activities, will bring up and stir up motivation in students to actively participate in activities. The highest expectation is the emergence of love for literacy activities in students. It all takes time, commitment, and sacrifice. However, all results will never betray the endeavor, all will be paid off if students become skyrocketed of all their potential so that it becomes a proud achievement and brings optimal benefit to others.

c. Literacy programs can increase reading interest and students' confidence because the stimulus provided is very diverse and takes place every day on various occasions.

d. Literacy programs make learning in school as meaningful learning that is rich in universal life messages.

\section{CONCLUSION}

Based on the explanation of the results of the research and discussion, it can be concluded that literacy programs are a digital requirement for someone to exist in life in this digital era. The unpreparedness of students will expose students to various obstacles that can be an obstacle to achieving various literacy skills and abilities in other fields optimally. For this reason, teachers must always actively strengthen the ability to read students understanding, create and innovate to create meaningful literacy activities (interesting, fun, and impressive) so that students will experience the benefits more and are motivated to actively participate in various literacy activities both in class and at school.

Suggestions that can be given are. Teachers should strive to always enrich their own insights by reading a lot of literature about the implementation of literacy activities in various countries that are well-known for their quality of education, such as Finland, Japan, Singapore, United Kingdom, United States and others so that they can always create diverse and meaningful literacy activities, and $b$. The teacher should always be eager to make himself a role model for students in terms of 'reading pleasure and writing pleasure' so that they can be transmitted more effectively and successfully to their students.

\section{REFERENCES}

[1] Burn, Paul C., Roe, Betty D., Ross, Elinor P. 1996. Teacing Reading in Today's Elementary Scools. Boston: Houhton Mifflin Company.

[2] Craig, Jennifer Lynn. 2013. Integrating Writing Strategies in EFL/ESL University Contexts: A writing-Across-the Curriculum Approach. New York: Wolsworth Publishing Company.

[3] Tompkins, Gail E. 2011. Literaci in The Early Grades: A Succassful Start for Prek-4 Reader and Writers. Boston: Allyn and Bacon.

[4] Gunawan, Imam. 2017. Pengantar Satistika Inferensial. Jakarta: Rajawali Pers.

[5] Gunawan, Imam. 2016. Metode Penelitian Kuantitatif. Retrieved 2 July 2019, from http://fip.um.ac.id/wpcontent/uploads/2015/12/2_Metpen-Kuantitatif.pdf. 